\title{
SOSIALISASI PENTINGNYA POLA HIDUP SEHAT GUNA MENINGKATKAN KESEHATAN TUBUH PADA MASYARAKAT DESA KALITORONG KECAMATAN RANDUDONGKAL KABUPATEN PEMALANG PROVINSI JAWA TENGAH
}

\author{
Andry Septianto, Wahyu, Syahreen Nurmutia, Niera Feblidiyanti, Junaenah \\ Universitas Pamulang \\ Email: dosen01303@unpam.ac.id
}

\begin{abstract}
The General purpose of this community service is to assist the people of Kalitorong village in addressing the problems faced today in improving and maintaining health by implementing a healthy lifestyle.The method that will be used in this community devotion is through counseling activities so that the people of Kalitorong village can apply a healthy lifestyle. In addition, providing training in maintaining and maintaining the health of the body to avoid various diseases. Health counseling is the same as Public Health Education, which is an activity or business to convey health messages to people, groups or individuals. From the training and counseling, it was concluded that during the training process, Kalitorong Village community enthusiastically participated in the training. This can be seen from the community response, the desire of people to be able to make Handsanitizer products, and ask the speaker or team PKM if there is difficulty when practicing the process of making handsanitizer. Furthermore, in this training also the community is taught in theory and practice by the PKM team about the use of empon-empon beverages in maintaining the health of the body so that the community can be avoided from a variety of diseases. The practice of making empon-empon is done from planting empon-empon in the yard until how to make an empon-empon drink easily. Besides, the community is also given a hot steam therapy extension that can help maintain endurance by PKM team.
\end{abstract}

Keywords : Kalitorong Village, Healthy Lifestyle, Handsainitizer Tradisional Empon-empon.

Abstrak

Tujuan umum dari kegiatan pengabdian kepada masyarakat ini adalah membantu masyarakat Desa Kalitorong dalam mengatasi persoalanpersoalan yang dihadapi saat ini dalam meningkatkan dan memelihara kesehatan dengan menerapkan pola hidup sehat. Metode yang akan digunakan dalam pengabdian masyarakat ini adalah melalui kegiatan penyuluhan agar masyarakat Desa Kalitorong dapat menerapkan pola hidup sehat. Selain itu, memberikan pelatihan-pelatihan dalam menjaga dan memelihara kesehatan tubuh agar terhindar dari berbagai macam penyakit. Penyuluhan kesehatan sama dengan pendidikan kesehatan masyarakat (Public Health Education), yaitu suatu kegiatan atau usaha untuk 
menyampaikan pesan kesehatan kepada masyarakat, kelompok atau individu. Dari hasil pelatihan dan penyuluhan disimpulkan bahwa selama proses pelatihan masyarakat Desa Kalitorong antusias mengikuti pelatihan. Hal ini dapat dilihat dari respon masyarakat, keinginan masyarakat untuk bisa membuat produk handsanitizer, dan bertanya kepada narasumber atau tim PKM jika ada kesulitan ketika mempraktekkan proses pembuatan handsanitizer. Selanjutnya, didalam pelatihan ini juga masyarakat diajarkan secara teori maupun praktek oleh Tim PKM tentang kegunaan minuman empon-empon dalam memelihara kesehatan tubuh sehingga masyarakat dapat terhindar dari berbagai macam penyakit. Praktek pembuatan emponempon dilakukan mulai dari cara menanam empon-empon di perkarangan rumah sampai cara membuat minuman empon-empon dengan mudah. Disamping itu, masyarakat juga diberikan penyuluhan terapi uap panas yang dapat membantu menjaga daya tahan tubuh oleh Tim PKM.

Kata Kunci : Desa Kalitorong, Pola Hidup Sehat, Empon-Empon, Handsanitizer

\section{A. PENDAHULUAN}

Raga yang sehat menjadi salah satu modal kesuksesan setiap orang dan raga yang sehat pun akan menunjang setiap kegiatan yang dilakukan oleh manusia. Raga yang sehat adalah raga yang terhindar dari penyakit sehingga setiap manusia harus menjaga kesehatannya agar raga tetap sehat. Hidup sehat merupakan impian dari setiap manusia dimana biasanya untuk memperoleh hidup yang sehat, manusia tersebut hanya perlu menjalankan pola hidup sehat sejak dini meski tidak ada batasan usia untuk memulai pola hidup sehat tersebut. Dewasa ini, pola hidup sehat sudah tidak dilakukan lagi karena berbagai aktivitas manusia yang banyak, sehingga tidak memiliki waktu untuk melakukannya. Akan tetapi, seharusnya melakukan pola hidup sehat itu penting untuk setiap manusia. Berangkat dari aktivitas manusia ini yang menentukan pola hidup sehatnya, dinilai sehat atau tidak berpengaruh terhadap implementasi kehidupan sehatnya (Sarinasiti, 2018).

Kalitorong adalah desa yang terleak di Kecamatan Randudongkal, Pemalang, Jawa Tengah. Di desa Kalitorong terlihat bahwa sebagian masyarakat yang menetap disana tidak menghiraukan masalah penerapan pola hidup sehat. Bila kita ketahui banyak sekali dampak negatif dari tidak melakukan hidup sehat tersebut, yakni timbulnya berbagai penyakit pada tubuh manusia. Penyakit yang disebabkan oleh virus dan hewan lain, seperti malaria, kolera, dan polio di masa modern masih bisa ditangani dengan baik melalui perawatan. Meski begitu, ada jenis penyakit baru yang bermunculan di masa modern ini dan tidak bisa ditebak pola penyebarannya, yaitu penyakit akibat gaya hidup yang salah. Contohnya, kurangnya kesadaran masyarakat dalam menjaga kesehatan pada saat melakukan aktivitas dalam kehidupan sehari-hari. Selain itu, ada masyarakat yang tidak mematuhi peraturan yang dibuat oleh pemerintah padahal akhir-akhir ini di Indonesia sedang menghadapi tantangan untuk melawan Corona Virus Disease 2019 atau Covid-19 (Junaedi, 2020).

Berdasarkan data dari Pusat Informasi dan Koordinasi Covid-19 Pemerintah Kabupaten Pemalang bahwa angka kejadian pasien terkonfirmasi positif Covid-19 yang diupdate oleh (Junaedi, 2020) selaku Ketua Gugus Tugas Penanggulangan Covid19 di Kabupaten Pemalang pada hari Sabtu, tanggal 02 Mei 2020 sebesar 25 orang. Oleh karena itu, dalam menghadapi Covid-19 harus mencoba berupaya melakukan pola hidup sehat dengan mengikuti aturan pemerintah untuk berada diam di dalam rumah atau menjaga jarak (social distancing). Selain itu, masyarakat juga harus memiliki perilaku hidup bersih dan sehat agar dapat memelihara 
kesehatannya.

Berdasarkan data yang diperoleh dari Laporan Rencana Strategis Dinas Kesehatan Provinsi Jawa Tengah Tahun 2018 sampai Tahun 2023 bahwa tingkat persentase Perilaku Hidup Bersih dan Sehat (PHBS) di Jawa Tengah sebesar 28\%. Jika dilihat dari persentase tersebut, maka banyak masyarakat yang tidak menjalankan perilaku hidup sehat padahal orang-orang dahulu memiliki tubuh yang sehat bahkan umur lebih panjang, namun mereka semua belum mengerti tentang pola hidup sehat secara alami atau hidup berkualitas. Hal tersebut dikarenakan mereka memakan makanan yang segar tanpa menggunakan pengawet dan tanpa ada zat-zat kimia sehingga orang-orang dahulu selalu bisa menjaga kesehatan. Mereka tidak mengonsumsi makanan siap saji yang mengandung zat kimia. Sedangkan, pada era modern seperti sekarang ini orang-orang terlalu sibuk bekerja, mengonsumsi zat kimia, lupa waktu makan, tidur tidak teratur, makan makanan siap saji, dan selalu meminum suplemen penambah energi.

Contohnya mereka yang masih di usia muda dan masih memiliki semangat yang kuat serta beranggapan bahwa tubuhnya masih kuat dan tidak bisa sakit. Padahal semua orang tahu bahwa penyakit bisa menyerang siapa saja baik usia muda maupun usia tua. Contoh lain dari orang yang tidak menghiraukan kesehatannya adalah orang-orang yang sibuk dengan pekerjaannya yang dimana meluangkan waktu untuk makan pun sering kali lupa sehingga sulit melakukan gaya hidup sehat. Di Indonesia khususnya, terdapat berbagai isu-isu terkini mengenai pola hidup yang dimulai dari pola hidup sehat dan pola hidup tidak sehat (Yulianto, 2019).

Menurut (Mesriah, 2017) bahwa pola hidup sehat didapat dari mereka yang memperhatikan keadaan tubuhnya, rajin berolahraga, makan, dan tidur yang cukup, hal ini menyebabkan tingkat kesehatan seseorang menjadi baik, hal ini akan menjadikan kualitas hidup seseorang meningkat. Sebaliknya, pola hidup tidak sehat yang mana didapat dari mereka yang tidak memperhatikan keadaan tubuhnya, makan yang tidak seimbang dengan aktivitasnya, dan jarang melakukan olahraga sehingga dapat memicu obesitas.

Menurut (Tarwaka, 2004) bahwa upaya pemeliharaan kesehatan tak akan berhasil jika tidak ada perubahan sikap mental dan perilaku sehingga setiap orang harus disiplin pada setiap ketentuan pola hidup sehat. Pola hidup yang sehat itu tentu dimulai dari diri sendiri. Lalu, jika kita sudah menerapkan pola hidup yang sehat, maka tentu lingkungan sekitar secara otomatis juga akan sehat. Pola hidup sehat adalah suatu usaha yang di lakukan manusia untuk menjaga kesehatan baik itu jasmani maupun rohani. Dengan cara memperhatikan makanan dan rutinitas kegiatan sehari-hari. Sebagai makhluk hidup kita tidak selalu sehat adakala kita sakit dan adakala kita sembuh. Maka dari itu dengan menerapkan pola hidup sehat, kehidupan kita akan selalu baik dan sehat. Tidak hanya kesehatan mental saja manusia juga harus memperhatikan kesehatan rohaninya. Sebab kesehatan mental akan rusak bila mana seseorang itu tidak sehat pada rohaninya. Maka dari itu dua pondasi ini merupakan pondasi utama dalam terciptanya pola hidup sehat.

\section{B. METODE PELAKSANAAN KEGIATAN}

Menentukan tujuan merupakan langkah awal dalam penyusunan suatu laporan kegiatan agar dapat berjalan dengan terencana dan searah. Tujuan umum dari kegiatan pengabdian kepada masyarakat ini adalah membantu masyarakat Desa Kalitorong dalam mengatasi persoalan-persoalan yang dihadapi saat ini dalam meningkatkan dan memelihara kesehatan dengan menerapkan pola hidup sehat. Secara khusus tujuan kegiatan pengabdian kepada masyarakat ini adalah a) Membantu masyarakat Desa Kalitorong dalam mengikuti program dicanangkan oleh Kementerian Kesehatan Republik Indonesia berupa Gerakan Masyarakat 
Hidup Sehat (GERMAS) yang bertujuan untuk memasyarakatkan budaya hidup sehat serta meninggalkan kebiasaan dan perilaku masyarakat yang kurang sehat. b) Membantu masyarakat Desa Kalitorong untuk menerapkan pola hidup sehat dalam kehidupan sehari-hari agar sadar, mau, dan mampu memelihara dan meningkatkan kesehatan. c) Membantu masyarakat Desa Kalitorong dalam melakukan pengukuran Nilai Angka Gizi sesuai standar dari World Health Organization (WHO), memberitahukan tata cara membuat minuman jamu tradisional, dan pemakaian handsanitizer secara sederhana untuk menjaga kesehatan fisik tubuh. d) Membantu untuk menumbuhkan rasa peduli diantara masyarakat Desa Kalitorong dengan didasari oleh keterbukaan, rasa saling menghargai, kesetaraan, keadilan, kejujuran dan nilai-nilai positif lainnya dalam memelihara dan meningkatkan kesehatan.

Metode yang digunakan dalam melakukan sosialisasi pola hidup sehat tersebut adalah metode demonstrasi, metode ceramah, dan metode diskusi kelompok. Metode diskusi kelompok adalah pembicaraan yang direncanakan dan telah dipersiapkan tentang suatu topik pembicaraan diantara $5-20$ peserta (sasaran) dengan seorang pemimpin diskusi yang telah ditunjuk. Kegiatan diskusi kelompok ini dilakukan antara masyarakat Desa Kalitorong dengan narasumber mengenai penerapan pola hidup sehat sesuai dengan program pemerintah Dinas Kesehatan Provinsi Jawa Tengah tentang Gerakan Masyarakat Hidup Sehat (GERMAS).

Metode ceramah adalah suatu cara dalam menerangkan dan menjelaskan suatu ide, pengertian atau pesan secara lisan kepada sekelompok sasaran sehingga memperoleh informasi tentang kesehatan. Ceramah ini akan diberikan oleh narasumber yang akan memberikan materi mengenai pola hidup sehat.

Metode demonstrasi adalah suatu cara untuk menunjukkan pengertian, ide dan prosedur tentang sesuatu hal yang telah dipersiapkan dengan teliti untuk memperlihatkan bagaimana cara melaksanakan suatu tindakan, adegan dengan menggunakan alat peraga. Metode ini digunakan terhadap kelompok yang tidak terlalu besar jumlahnya. Demonstrasi ini dilakukan dengan video mengenai cara penggunaan dan membuat produk handsanitizer kepada masyarakat Desa Kalitorong, video cara melakukan terapi uap panas yang bisa dilakukan oleh masyarakat di rumah masing-masing, dan video pembuatan minuman herbal berupa empon-empon sehingga masyarakat Desa Kalitorong dapat memelihara dan menjaga kesehatan dengan baik saat melakukan aktivitas sehari-hari.

Evaluasi kegiatan dilakukan setelah kegiatan penyuluhan dan pelatihan kepada masyarakat Desa Kalitorong Pemalang yaitu dengan cara mengisi instrument yang disiapkan oleh TIM PKM terkait bagaimanakah tanggapan Masyarakat Desa Kalitorong Pemalang, Jawa Tengah, terhadap kegiatan PKM yang dilakukan oleh Tim Dosen Teknik Industri Universitas Pamulang.

Hal mendasar yang ditawarkan untuk alternatif pemecahan masalah adalah melalui kegiatan penyuluhan dan pelatihan kepada sebagian masyarakat Desa Kalitorong yang dikemas dengan nama kegiatan "Sosialisasi Pentingnya Pola Hidup Sehat Guna Meningkatkan Kesehatan Tubuh Pada Masyarakat di Desa Kalitorong, Kecamatan Randudongkal, Kabupaten Pemalang, Provinsi Jawa Tengah”. Untuk lebih jelasnya dapat dilihat dalam skema di bawah ini: 


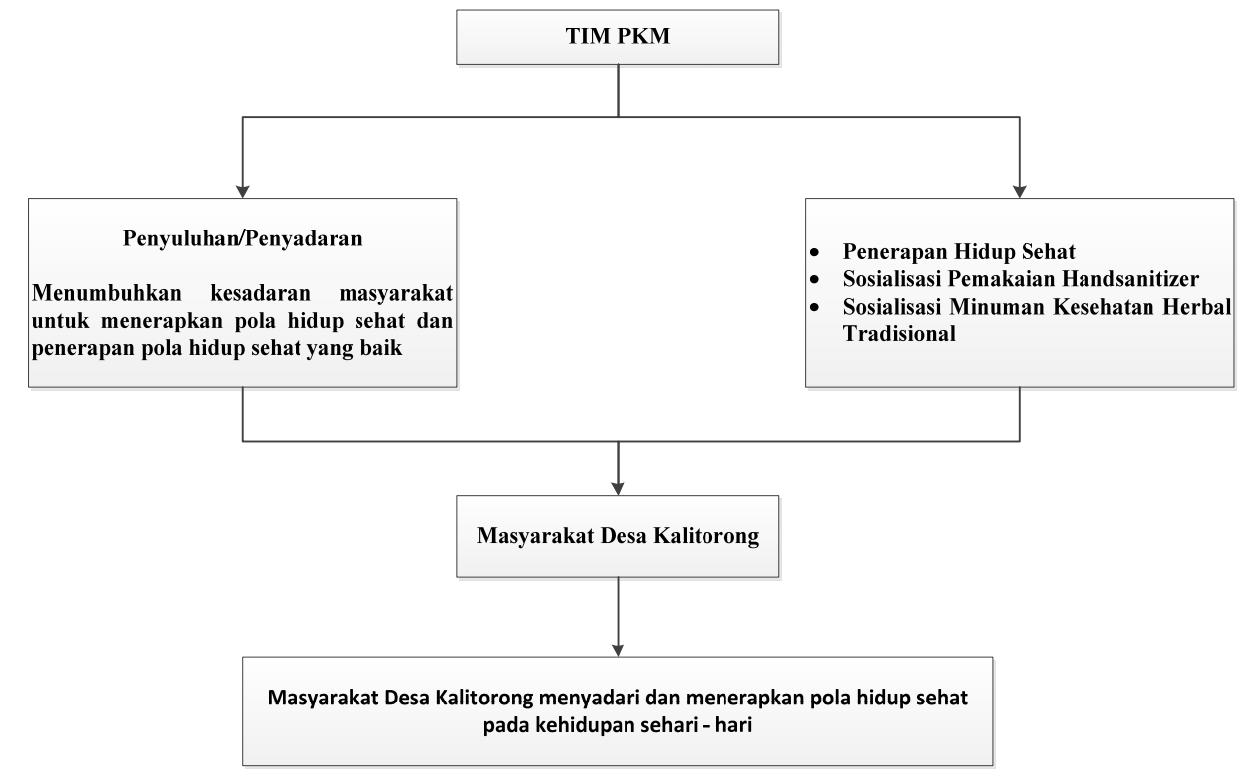

Gambar 3.1 Kerangka Pemecahan Masalah

\section{HASIL DAN PEMBAHASAN}

Materi yang akan dijelaskan dalam kegiatan Pengabdian Kepada Masyarakat melalui media penyuluhan aplikasi Zoom Meeting tentang "Sosialisasi Pentingnya Pola Hidup Sehat Guna Meningkatkan Kesehatan Tubuh Pada Masyarakat di Desa Kalitorong, Kecamatan Randudongkal, Kabupaten Pemalang, Provinsi Jawa Tengah” yang ditunjukkan pada Gambar 4.1 berikut:

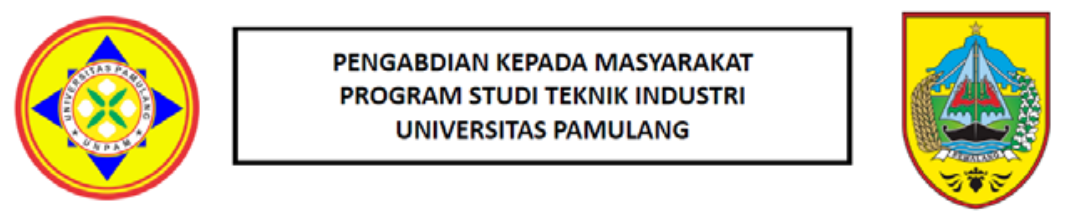

\footnotetext{
"Sosialisasi Pentingnya Pola Hidup Sehat Guna Meningkatkan Kesehatan Tubuh Pada Masyarakat Desa Kalitorong Kecamatan Randudongkal, Pemalang, Jawa Tengah"
}
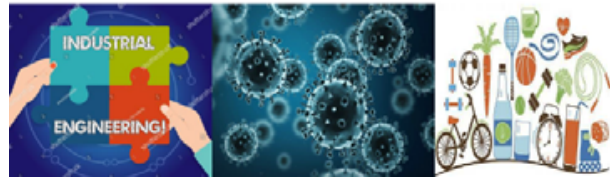

Kamis, 14 Mei 2020 Via ZOOM

\section{Gambar 4.1 Materi Pelaksanaan Pengabdian Kepada Masyarakat}

Kemudian, tujuan dari kegiatan Pengabdian Kepada Masyarakat ini adalah membantu masyarakat Desa Kalitorong melawan virus dengan penerapan pola hidup sehat, membantu masyarakat Desa Kalitorong membuat jamu demi mempertahankan imun tubuh, dan membina berkelanjutan untuk kegiatan PKM ini di Desa Kalitorong. Pola hidup sehat adalah suatu usaha yang dilakukan manusia untuk menjaga kesehatan baik secara jasmani maupun rohani. Guru besar Universitas Airlangga (UNAIR), Chairul Anwar Nidom, menawarkan pendekatan berbeda dalam penerapan pola hidup sehat. Ia mengusulkan masyarakat agar 
mengonsumsi empon-empon untuk membantu melindungi diri dari virus. "Empon-empon" adalah istilah yang biasa dipakai para ibu rumah tangga di pedesaan untuk bumbu-bumbu yang biasanya terdiri dari jahe, temulawak, kunyit, lengkuas, kunir, sereh, dan sebagainya. Menurut Nidom, empon-empon mengandung senyawa curcumin yang bisa mengendalikan produksi sitokin di dalam paru-paru dan menjaga imun tubuh. Adapun manfaat-manfaat lainnya dari empon-empon, antara lain:

1. Dapat membantu meningkatkan kekebalan tubuh manusia, antara lain melalui aktivitas antioksidan dan antiinflamasi, agar tidak mudah terkena infeksi virus dan bakteri.

2. Dapat berpikir sehat dan positif sehingga seseorang dapat bekerja lebih maksimal.

3. Dapat membantu meningkatkan stamina didalam tubuh.

4. Dapat menghemat biaya kesehatan.

Selanjutnya, terdapat langkah-langkah membuat minuman jamu empon-empon, yaitu:

1. Pertama-tama, bakar jahe di atas api sedang, kupas atau buang kulitnya lalu memarkan.

2. Selanjutnya, rebus air dalam panci, tambahkan jahe, temulawak, kunyit, kayu manis, gula aren, garam dan sereh.

3. Masak, dengan api kecil hingga air menyusut kurang lebih sebanyak $750 \mathrm{~mL}$, lalu angkat.

4. Saring air empon empon, pindahkan ke dalam gelas saji. Hasil wedang empon-empon ini berwarna kecoklatan sedikit pekat hampir sama dengan wedang uwuh.

5. Sajikan empon-empon selagi hangat agar lebih enak dan menghangatkan badan.

Dari hasil pelatihan dan penyuluhan disimpulkan bahwa selama proses pelatihan masyarakat Desa Kalitorong antusias mengikuti pelatihan. Hal ini dapat dilihat dari respon masyarakat, keinginan masyarakat untuk bisa membuat produk handsanitizer, dan bertanya kepada narasumber atau tim PKM jika ada kesulitan ketika mempraktekkan proses pembuatan handsanitizer. Selanjutnya, didalam pelatihan ini juga masyarakat diajarkan secara teori maupun praktek oleh Tim PKM tentang kegunaan minuman empon-empon dalam memelihara kesehatan tubuh sehingga masyarakat dapat terhindar dari berbagai macam penyakit. Praktek pembuatan empon-empon dilakukan mulai dari cara menanam empon-empon di perkarangan rumah sampai cara membuat minuman empon-empon dengan mudah. Disamping itu, masyarakat juga diberikan penyuluhan terapi uap panas yang dapat membantu menjaga daya tahan tubuh oleh Tim PKM. Setelah kegiatan PKM ini dilaksanakan, maka diharapkan nanti masyarakat Desa Kalitorong bisa mempraktekkan sendiri dirumah dari penggunaan hand sanitizer, terapi uap panas, dan mengkonsumsi minuman empon-empon. Berikut ini adalah grafik yang memperlihatkan tingkat pemahaman masyarakat Desa Kalitorong tentang penerapan pola hidup sehat berdasarkan pengisian kuesioner dimana skor 5 adalah sangat paham, skor 4 adalah paham, skor 3 adalah kurang paham, skor 2 dalah tidak paham, dan skor 1 adalah sangat tidak paham. 


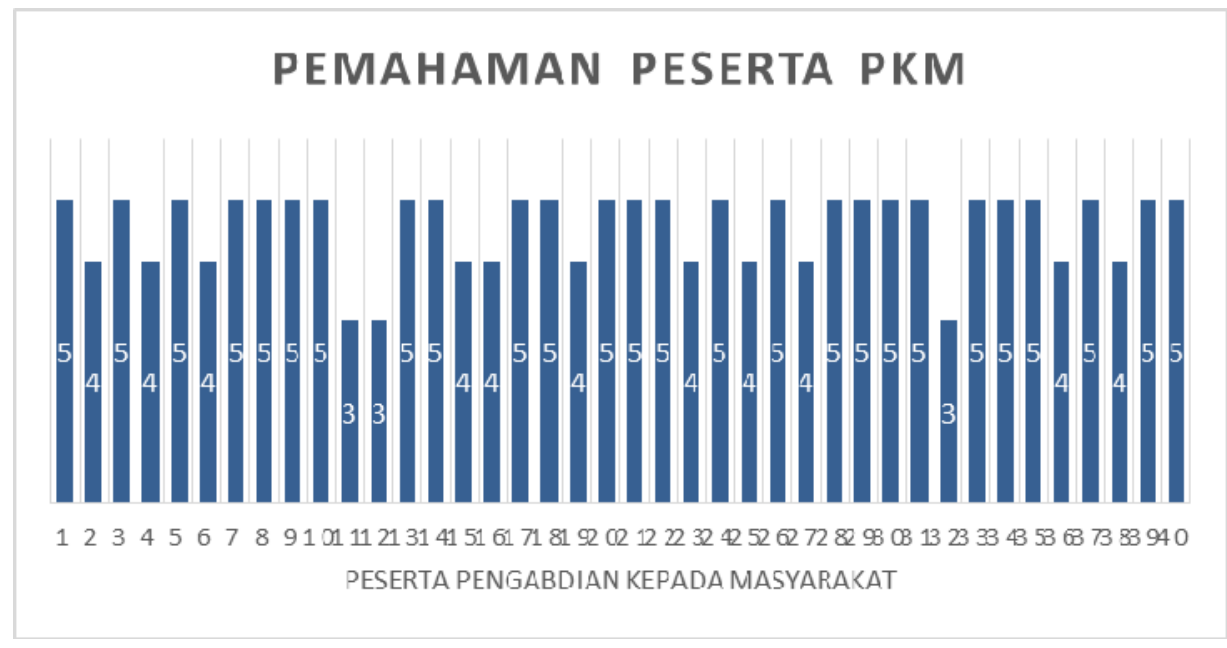

\section{KESIMPULAN DAN SARAN}

\section{Simpulan}

Pola hidup sehat merupakan suatu keagiatan yang dilakukan secara terus-menerus dan teratur, sehingga menjadi kebiasaan dalam gaya hidup dengan memperhatikan hal-hal yang memengaruhi kesehatan tubuh, baik dari konsumsi makanan dan minuman, olahraga, dan juga istirahat yang cukup. Pelaku pola hidup sehat akan selalu berusaha untuk setiap aktivitas dalam kehidupannya untuk selalu teratur dan seimbang dalam menjaga kesehatan tubuhnya. Menerapkan pola hidup sehat dalam kehidupan sehari-hari sebenarnya memiliki banyak manfaat bagi tubuh manusia.

Bahkan, bila menerapkannya dengan cara yang benar, maka dampak positif yang dirasakan akan berlangsung dalam jangka waktu yang lama dan dapat mencegah dari serangan berabagai macan penyakit, mulai dari yang ringan hingga penyakit yang kronis. Oleh karena itu, kesehatan sangatlah penting untuk meraih kebahagiaan hidup. Syarat utama seseorang dapat menikmati kebahagiaan dalam hidup ini adalah saat mereka memiliki kesehatan secara jasmani dan rohani. Pengertian hidup sehatini menjadi cara seseorang untuk menuju kebahagiaan hidup. Salah satu cara agar kita sehat yaitu dengan membiasakan dan menjalani pola hidup sehat

\section{Saran}

Berdasarkan hasil kegiatan Pengabdian Kepada Masyarakat, maka kami dari Tim Dosen Universitas Pamulang memberikan saran diantaranya sebagai berikut:

1. Menerapkan pola hidup sehat sangatlah baik dalam menjaga imun tubuh dengan meminum jamu empon-empon menyehatkan tubuh dan dengan menanam jamu empon-empon yang telah di jelaskan dalam pengabdian kepada masyarakat dapat menghemat biaya.

2. Menerapkan pola hidup sehat dengan menerapkan olahraga dalam satu hari minimal 1 jam.

\section{Ucapan Terima Kasih}

Rasa syukur dan suka cita kami haturkan kepada segenap pihak yang telah mensukseskan kegiatan PKM dengan judul "Sosialisasi Pentingnya Pola Hidup Sehat Guna Meningkatkan Kesehatan Tubuh Pada Masyarakat Desa Kalitorong Kecamatan Radudongkal Kabupaten Pemalang Provisnsi Jawa Tengah” kepada: 
1. Rektor Dr. H. Dayat Hidayat, M.M, Rektor Universitas Pamulang Tangerang Selatan Banten.

2. Dr. Ali Maddinsyah, S.E., M.M., selaku Ketua LPPM Universitas Pamulang Tangerang Selatan - Banten.

3. Rini Alfatiyah S.T,M.T, CMA., selaku Ketua Program Studi Teknik Industri Universitas Pamulang Tangerang Selatan - Banten.

4. Tedi Dahniar,S.T,M.T., Selaku Sekertaris Program Studi Teknik Industri Universitas Pamulang Tangerang Selatan - Banten.

5. Suharto., selaku Kepala Desa Kalitorong.

6. Dosen-dosen Teknik Industri Universitas Pamulang yang ikut berkolaborasi dalam Pengabdian Kepada Masyarakat.

7. Mahasiswa Universitas Pamulang yang juga ikut berkontribusi terhadap kelancaran kegiatan PKM.

\section{DAFTAR PUSTAKA}

Bridger, R. (2003). Introduction To Ergonomics 2nd Edition. London And New York: Taylor And Francis.

Ginting, M. (2018). www.promkes.kemkes.go.id/8-langkah-menuju-pola-hidup-sehat.

Hidayat. (2020). www.wikipedia.org/wiki/Kesehatan.

Kotler, P. (2002). Marketing Management. New Jersey: Prentice Hall.

Mesriah. (2017). https://www.papermakalah.com/2017/09/makalah-pola-hidup-sehat.html.

Nadya. (2013). www.uin-alauddin.ac.id/tulisan/detail/konsep-sehat-dan-sakit.

Nurmianto, E. (2008). Ergonomi Konsep Dasar dan Aplikasinya. Surabaya: Guna Widya.

Pane, d. M. (2020). https://www.alodokter.com/virus-corona.

Sarinasiti, R. (2018). Analisis Pengetahuan Perilaku Hidup Sehat Dan Pemanfaatan Puskesmas. Jurnal Kesehatan Masyarakat Volume 8 Nomor 1 Universitas Islam Muhammadiyah Palu.

Sutalaksana, I. (2006). Teknik Perancangan Sistem Kerja. Bandung: ITB Bandung.

Tarwaka. (2004). Ergonomi untuk Keselamatan, Kesehatan Kerja dan Produktivitas. Surakarta: UNIBA Press.

WHO. (2010). Preventing and Managing The Global Epidermis. Geneva: WHO Techincal Report. 